\title{
Land Suitability Evaluation to Determine the Appropriate Areas of Development: A Case Study of Hormuz Island
}

\author{
Ameneh Ahmadi', Hassan Mohamadian Mosammam², Navab Mirzaei ${ }^{3}$ \\ ${ }^{1}$ Department of Environmental Planning, Management and Education, Tehran University, Tehran, Iran \\ ${ }^{2}$ Department of Geography and Urban Planning, Shahid Beheshti University, Tehran, Iran \\ ${ }^{3}$ Department of Urban Design, Shahid Beheshti University, Tehran, Iran \\ Email: Ameneh.ahmadi.a@gmail.com
}

How to cite this paper: Ahmadi, A., Mosammam, H.M. and Mirzaei, N. (2017) Land Suitability Evaluation to Determine the Appropriate Areas of Development: A Case Study of Hormuz Island. Open Journal of Ecology, 7, 518-534.

https://doi.org/10.4236/oje.2017.79035

Received: June 28, 2017

Accepted: August 2, 2017

Published: August 5, 2017

Copyright ( 92017 by authors and Scientific Research Publishing Inc. This work is licensed under the Creative Commons Attribution International License (CC BY 4.0).

http://creativecommons.org/licenses/by/4.0/

\begin{abstract}
One of the basic prerequisites for the development of spatial programs and policies is evaluating the land suitability for future land uses based on the principals of ecological sustainability. This analysis is critical in islands due to special characteristics such as limited natural resources, interdependent and more complex ecosystems, high vulnerability to natural hazards, climate change and economic vulnerability. Accordingly, this paper based on the ecological approach and using Geographic Information System software package and Analytic Hierarchy Process and developing appropriate criteria has analyzed the land suitability of Hormuz Island. The findings clearly show the land suitability to develop industrial, agriculture, tourism land uses and can be the basis for planning the future development of the island based on the ecological sustainability.
\end{abstract}

\section{Keywords}

Land Suitability Assessment, Multi-Criteria Decision Making, Land Use, Hormuz Island

\section{Introduction}

The efficient use of land-as a scarce and non-productive item-is a key step toward sustainable management and development of each region. In this regard, evaluating the land suitability is one of the major tools to achieve this goal. In other words, identifying suitable future land uses based on ecological approach is crucial for sustainable land use planning [1]. Analyzing or evaluating of land 
suitability is the determination process of certain future land use based on specific criteria [2]. If the ecological integration and prospects are considered and placed in the core analysis, the ecological label is also added to it and ecological sustainability is prioritized by any development plan and policy. Meanwhile, such an analysis on the islands is much more important than the inland continent due to its different characteristics. In other words, the limited natural resources and living spaces, interconnected and more complex ecosystems, high vulnerability to natural hazards, as well as critical and sustainable economic and climate change, have made the evaluation of land suitability with an ecological approach, a prerequisite for any species action of planning and decision making.

\subsection{Land Capability}

Achieving sustainable development requires the rational planning and the exploitation of natural resources must be based on the carrying capacity of the environment [3]. Unplanned development is one of the main problems in developing countries. In order to achieve the goals of sustainable development, as a basis for the study of land use planning is a needed action to realize the development process, to adapt the development to environmental capabilities [4]. Determination of the potential and appropriating using of the land is a method that is appropriate for the natural capabilities, the needs of communities and the use of human activities in space, to establish a rational and stable relationship [5]. The land capability assessment defines and evaluates land development units from a common point of view without notice the kind of its use [5]. Wells (2001) believes land capability is "the ability of the land to support a particular type of use without causing permanent damage". The land capability classification creates a guideline for the evaluation of soil restriction and land management suggestions for use at different scales including state, area, and the exclusivity planning level [6]. Sustainable development can be achieved when land is to be used suited to its potentials and capabilities. Accordingly, the identification of the potential and capabilities prior to deployment on its territory and loading uses and activities is very important. Otherwise, the development will take place in such a way that natural and ecological constraints hinder the continuity of activities and virtually many investments will be wasted.

Land Capability is an environmental data set that is effective in human economic productivity and is applicable to human economic activities in the environment. Therefore, the abilities of the natural and human environments consist of both available capabilities and the potential capabilities of the region, and these potential capabilities have an enormous scope that, with its precise recognition and evaluation, we can easily illustrate the image of future development [7]. The land capability is forming process on eight geographic data and information on environment, socio-culture and economic. There are nine variables used to find out the land capability indicator including water supply, slope stability, morphology forms, erosion potential, drainage availability, and waste 
disposal [8]. Silpa T. Ja, et al. illustrates the land capability is depended on several parameters as the types of soil, its depth, and texture, underlying geology, hydrology, topography, etc. These parameters restrict the land accessible for various purposes. Classification of Land capability is done using the different factors including soil texture, permeability, Slope, soil depth, and erosion maps factors. [9].

\subsection{Land Suitability}

In order to achieve the goals of sustainable development, the evaluation of land suitability as a major study in the land use planning is an essential step for the development process to be tailored to the environmental capabilities of each region [10]. Ritung $\mathrm{S}$ et al. expresses "land evaluation is a process for matching the characteristics of land resources for certain uses using a scientifically standardized technique". The outcomes can be applied as a guideline by land use planners to recognize alternative land uses. Land Suitability is the rating of proportion of land for a specified use. Land suitability could be determined for the present condition that means "Actual Land Suitability" or after improvement that means "Potential Land Suitability" [11]. Land suitability resources to the ability of a land, which is to ensure the consumption in a sustainable way. Its evaluation prepares information on the limitations and opportunities for the utilization of the land and so instructs decisions on optimal uses of resources. $\mathrm{Ab}$ del Rahman M.A.E et al believe "knowledge is an essential prerequisite for land use planning and development" [5].

The suitability evaluation of the land determines the relationship between Economic-social impacts and land-use changes in order to monitor sustainable development [12]. In fact, the evaluation of land suitability is a tool for identifying potential and types of usage that a land naturally can benefit from them [13].

Since some of the natural resources have been limited the environmental potential for human use, assessing land suitability and the appropriateness of ecologic should be seen as an important step in planning [14]. In fact, the assessment of the land and environmental suitability (whether it is ecological, economic and social) is to estimate the possible use of human of land for agricultural, pasture, forestry, park (conservation, tourism), water supply uses, military affairs and engineering and urban, industrial and rural development in the framework of agricultural, industrial, service and trade uses [13]. Therefore, land suitability can be considered as potentialities of the land in relation to its ecological capabilities for development. On this basis, prior to any intervention in the land, the land suitability of that area or region should be evaluated in order to evaluate the appropriateness of the development, based on this suitability and with the consideration of economic and social needs, to choose the appropriate development. Land suitability evaluation is actually the highest and most difficult stage of land use preparation and provides basic information for the second phase of land use, which includes the selection of appropriate land use and sys- 
tem management [15].

\subsection{Research Background}

Over the past decades, thanks to advancements in GIS technology and multicriteria decision-making methods, as well as increasing environmental concerns caused by human malicious activities and inadequate development, many researchers in the north and south have analyzed land suitability, which some of them are mentioned as follows.

Mansir [16] in his paper titled "GIS and multi-criteria analysis" has used the hierarchical analytical quotient and hagiographic information system to properly plan. This study examines the value and biodiversity of the Johor Ramsar wetland in Malaysia for conservation and development. Examined criteria include the age of tree, harvest season, the rate of endangered plants, and the proximity of the habitat to the use of natural land with vegetation, habitat areas and water quality. The results of the study indicate the ability to make multi-criteria decisions in conjunction with the GIS for tourism planning. Kia [17] presented a model for developing tourism in suburban areas in the study of Fing Quan District, Zinjiang City, China. In this research, the hierarchical analysis process model has been deployed. At the first level, the goal of the project was to develop tourism in the Fing Quan District of Zinjiang, and in the second level, four criteria including ecological significance, economic significance, the importance of outlook, social significance have been used. In the end, they came to the conclusion that the $89 \%$ scale area is suitable for tourism development. Raymond and colleagues [18], in their study using fuzzy inference system using a geospatial approach, evaluated the agricultural capability using two linear weight composition methods and a hybrid combination method. In the study area, the combined method of Jaeger was more suitable than the linear weight composition method. The results of integrating the fuzzy inference system with the geographic information system indicate that this method is capable of examining a large amount of information and usable to evaluate land suitability.

Mirdavoodi et al. [19] studied and determined the land suitability of Markazi Province in terms of agriculture and pasture using the GIS. Their results indicated that the areas with a capability level of 1 are mainly located around groundwater resources more than 7000 cubic meters per hectare, with a gradient of -0.5 and high-grade soils with a deep texture and low erosion. Mahmoudi [20], evaluated the recreational capability of the customary lagoon in the forests of the city of Lordegan. He used the parametric evaluation method, based on optimal jitter and ranking the relevant indexes in the GIS environment and specified proper areas for recreational planning to two forms: Centralized tourism and extensive tourism. Minaei [21] implemented the agricultural planning model using fuzzy logic and geographic information system (GIS) in Fereydoun city's region. In this study, according to slope information, soil texture, soil structure, soil depth and other effective factors, favorable regions according to the degree 
of their capability are identified for farming.

\section{Materials and Methods}

\subsection{Setting}

The study area is Hormuz Island. Hormuz is an island located in Hormuzgan province, $18 \mathrm{~km}$ from Bandar Abbasi and $20 \mathrm{~km}$ from Qeshm Island. The area of the island is 45 sq. $\mathrm{Km}$. It has geographic coordinates between $27^{\circ} 6^{\prime} 6^{\prime \prime}$ and $27^{\circ} 1^{\prime} 58^{\prime \prime}$, and the geographical latitudes are between $56^{\circ} 25^{\prime} 15^{\prime \prime}$ and $56^{\circ} 30^{\prime} 10^{\prime \prime}$ in the Persian Gulf. The island is inhabited by more than 5700 people (according to the census of 2011) and is the only settlement area is Hormuz. Despite the capabilities of the island, Hormuz is one of the most deprived regions of the country in terms of facilities and features of Welfare, Housing, Employment, Education, access to Urban Services and many social and economic fields and is faced with many problems in the field of sustainable development. Figure 1 shows the location on Hormuz Island.

The island of Hormuz is one of the islands that have been of great importance throughout history through its geographic and strategic location in terms of military, political, social, economic and environmental issues. The existence of the Red Soil Mine, the presence of more than 5800 inhabitants (in 2011) beautiful

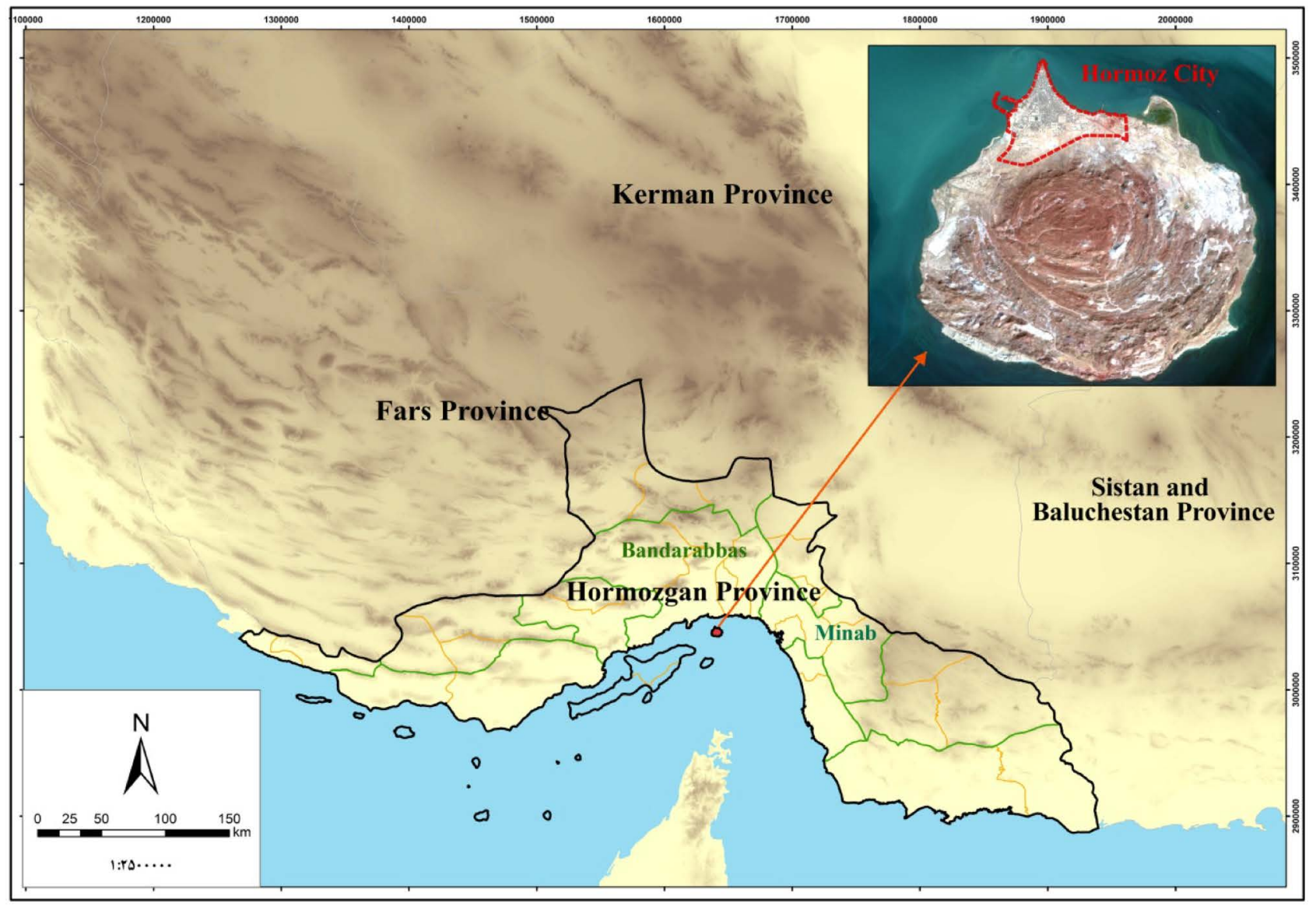

Figure 1. Location of Hormuz Island. 
landscapes, a large variety of minerals and geological outcrops, the presence of coral reefs, rocky beaches, sea caves and the diverse forms of the coastal coast alongside the indigenous vegetation and wildlife living on the island and some historical and cultural memorials associated with native life are some of the special characteristics of the island of Hormuz. However, the island faces issues such as proper and smoothly land restrictions, the unplanned use of land resources, the unfavorable and sprawl development of the city of Hormuz, the violation of the norms, the salinity of surface water due to salt dome in the center of island, the vulnerability of the coastal edge of the city in the face of successive storms, a number of endangering animal and plant species (according to The IUCN Red List of Threatened Species), high seismicity, severe coastal erosion and other such challenges. However, due to resource constraints on the island, land use development requires the wise use of land capacities to meet the people's needs for water, food, building materials and the desirable quality of life, and to maintain the functioning of natural life support systems. Based on this, the present study analyzes the land suitability of the island in other to sustainable development with an ecological approach.

\subsection{Research Method}

The method used in this research is a quantified method and the software package of the GIS and its overlapping techniques, as well as a hierarchical process analysis, have been used to evaluate the criteria used. In other words, for data integration and aggregation, the information layer layout has been used. The process of data integration and the mapping of environmental units in the GIS involves the combination of stable functions (form of land, rock, soil, and vegetation), and the production of environmental units mapping along with the characteristics table of environmental units. Finally, this table has been completed for each unit with other ecological unsustainable features (climate, water resources, and wildlife). The integration of the GIS with the hierarchical analysis process has many advantages in assessing land suitability with the ecological approach and it can be used to determine suitable and unsuitable areas for different lands [22]. In this study, the criteria used to measure land suitability for tourism, industrial, agricultural and conservation development are separately evaluated. Data collection is based on library tools and field studies and observations. The information needed is also gathered from the Iranian Statistics Center, the Organization of Meteorology of the province, the Geological Survey of Iran, the Institute of Water and Soil Research, and the General Directorate of Environmental Protection of Hormuzgan, the General Directorate of Natural Resources of Hormuzgan Province and the Geographic Organization of the Armed Forces.

The steps involved in doing the job are summarized as follows:

1) Determination of variables and evaluation criteria: These criteria are determined in relation to the general situation of the problem in Hormuz Island. 
2) Logging of variables and criteria into GIS (Geographic Information System): This stage is a process that includes data acquisition, format changes, the georeferenced, setting and documenting the data.

3) Providing the new layers of information: At this stage, according to existing data, new information layers such as distance from communication networks, distance from gas and power lines and other items are provided. Also, the mapping of the land use map to the Raster's map was made at this stage.

4) Classification and Valuation of Variables and Layers of Information: At this stage, which is one of the main stages of locating using the GIS, the sum of variables and criteria have been classified and valued. In this research, an analysis hierarchical process model has been used to evaluate the information layers and weighing the criteria is done in the Expert Choice. The method is that in the beginning a hierarchy of the desired problem has been created that in this hierarchy, the goals, criteria, and sub-criteria are determined. Then the elements in each level of the hierarchy are evaluated from bottom to top relative to all related elements in the higher level, respectively. Hence, decision options are assessed on the basis of all other decision indicators. Finally, a pair comparison matrix is created that is composed of numbers 1 to 9 relative to the importance of the factors. After the matrix is formed, the relative weight of the criteria is obtained and after determining the weight of the criteria and sub-criteria, these weights are entered into information tables of information layers and these information tables are provided with an elaboration of maps.

Combining information layers and generating final map: After identifying effective criteria for locating and identifying their weight, these information layers should be combined using an appropriate method. The integration of maps is achieved from overlapping weighted maps. Combining different layers of space from different sources together is the main goal of the GIS project and its unique feature, in this way the interactions are described and analyzed, with the help of relevant models, prediction of the future status, to provide the necessary ground for decision makers [23]. In this study, to combine the layers of information together, the index overlap model is used. Based on this, and with the deployment of the GIS, the information layers collected are combined and according to the rating of the information layers, the final assessment maps have been provided for the development of tourism, protection, industrial and agricultural areas of Hormuz Island.

\section{Results}

\subsection{Land Suitability for Tourism}

The island of Hormuz has a variety of historical, natural and cultural attractions. Its historic attractions, such as the Portuguese fortresses, the Jerry Pollack School, the Bibigol Palace, the Bell Tower, the Pink Palace, the Saffron Market and its natural attractions, including the diverse beaches around the island for swimming, diving, sea corals, Mangrove forests (as Protected area and genetic 
reserve), its 70 colored soil, the red soil mine, the white mountains, the salt caves, the valley of sculptures, the spectacular lawns, and the cultural attractions of Khezr holy shrine, the carpet of the soil and the handicraft of the island can be mentioned. Among the most important features of the island's tourism is its climate-friendly nature with the students' mid-term holidays and the holiday of Nowruz when in other regions of the country, the weather is cold and fairly winter, and in this area, the climate is perfectly suitable. Tourism is classified in two types of tourism in closed environments and tourism in open environments. The assessment of a suitable place for tourism is the first type of land suitability function for urban development. So, here's the second category tourism. Figure 2 shows Hormuz Island's land suitability for tourism. Table 1 indicates the environmental measures and their descriptions and rates that we employed for tourism land suitability.

As you can see in the Figure 2, the northern, eastern and western lands near the coast of the island, especially in the northern part, have a more favorable sit-

Table 1. Environmental measures for tourism in the island of Hormuz.

\begin{tabular}{|c|c|c|}
\hline Measures & Description & Final rating \\
\hline \multicolumn{3}{|l|}{ Climate } \\
\hline \multicolumn{3}{|l|}{ Land form } \\
\hline Height classes & Pitch lands, plains and slopes ranging from zero to 20 meters & 0.034 \\
\hline Slope & $0 \%-5 \%$ & 0.201 \\
\hline Geographical direction & East and south & 0.201 \\
\hline \multicolumn{3}{|l|}{ Soil and ecology } \\
\hline Type of soil and mother rock & Looney and sandy hills & 0.039 \\
\hline Earthquake & There are no more than 6 Richter earthquake records in these areas (affecting the whole island & level). \\
\hline \multicolumn{3}{|l|}{ water resources } \\
\hline Access to water resources & 40 - 150 liters per day per person & 0.039 \\
\hline Groundwater & Underground aquifers do not have a developmental limit and the groundwater level be at least & 10 meters. \\
\hline \multicolumn{3}{|l|}{ Other } \\
\hline Plant cover density & Regarding the climate of the region, it is preferable to have green spots. & 0.039 \\
\hline Tourist attractions & $\begin{array}{l}\text { Minimum distance and best access to tourist attractions. Tourist points with a radius of } 500 \\
\text { meters are considered. }\end{array}$ & 0.301 \\
\hline protected areas & $\begin{array}{l}\text { Be not in areas under the management of the Environmental Protection Agency and forests } \\
\text { and pastures. Minimum distance of } 30 \mathrm{~km} \text { is recommended }\end{array}$ & 0.228 \\
\hline Potential of air pollution & $\begin{array}{l}\text { The position of the land is not a valley, and in the dominant wind direction (southwest) } \\
\text { pollution of various industrial units or other pollutants (the urban part of Hormuz is in the } \\
\text { part of the island) }\end{array}$ & $\begin{array}{l}\text { lue to the air } \\
\text { northernmost }\end{array}$ \\
\hline Access to infrastructure & There is a possibility of infrastructure development in the proposed recreational areas. & 0.120 \\
\hline
\end{tabular}

Source: authers. 


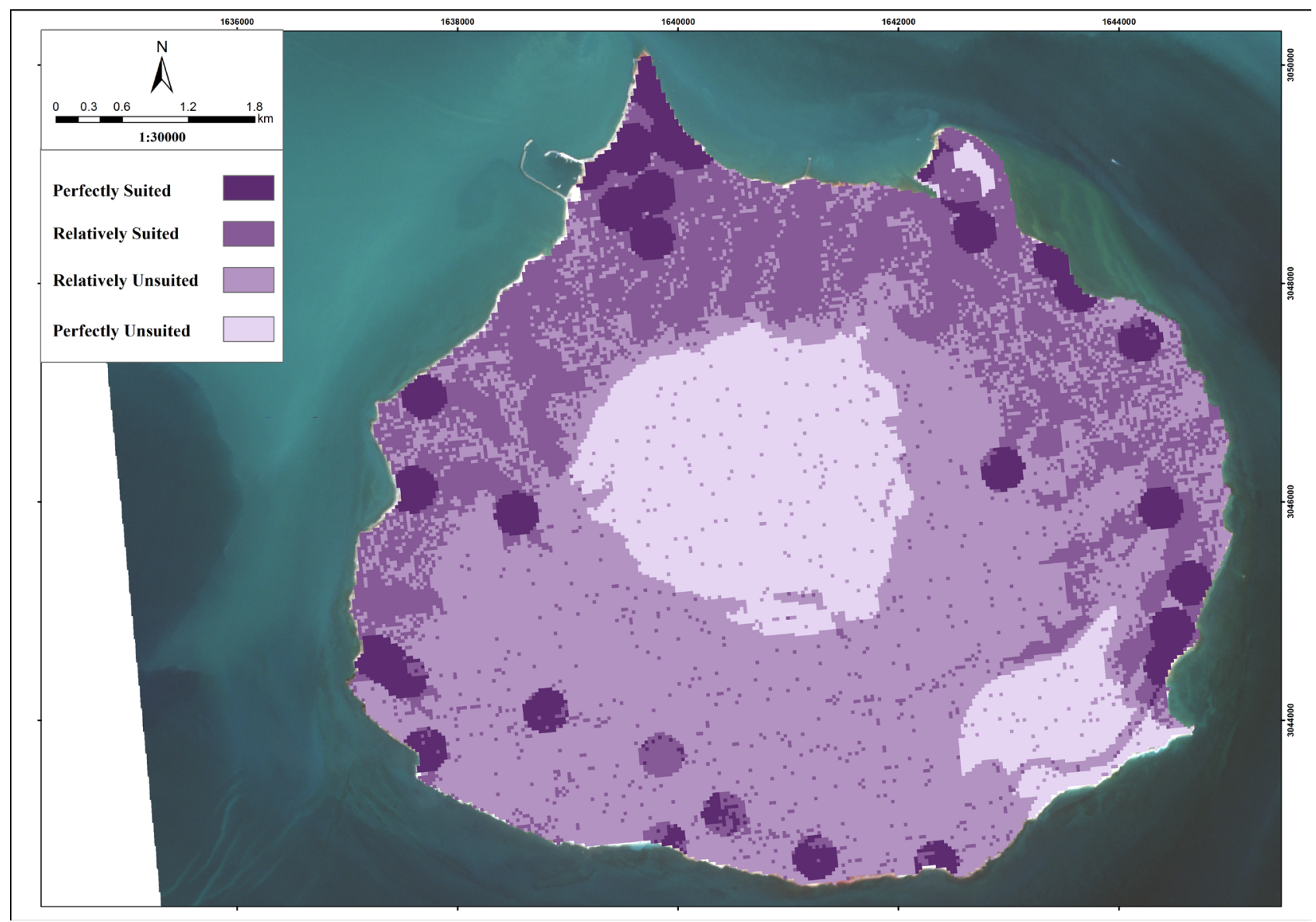

Figure 2. Hormoz Island's land suitability for tourism.

uation for tourism development. In addition, tourist attractions are also perfectly suitable places for tourism development.

\subsection{Land Suitability for Industry}

According to the Iranian Census in 2011, the unemployment rate in Hormuz is more than 18 percent. The most frequent employment in Hormuz Island was in the fishing group (32\%), followed by the administrative group (13\%), and then in the construction and transportation group ( $9 \%$ each). This indicates an inappropriate situation in employment in the industry. Social studies also show that the number of people with university education is very limited, about $4.5 \%$ in 2011, and 7\% in 2016, which shows the inappropriateness of supporting industrial activities on the island. At the same time, the long-term neglect of the island of Hormuz has caused the lack of infrastructure development, especially the proper ways of land-based communication (within the island) and offshore, proper drinking water and sewage treatment. This weakness in infrastructure has affected the development of various parts of the industry on the island. The environmental features of the site are similar to those of the city, in addition to the rules and regulations of the environmental organization in relation to the type of industry and the required distance from the urban area. Accordingly, the 
Group "D" Industries with a distance of $1000 \mathrm{~m}$ and the group "E" with a distance of 1500 from the city can be developed. Figure 3 shows Hormuz Island's land suitability for the industry. Table 2 indicates the environmental measures and their descriptions and rates that we employed for industrial land suitability.

As you can see in the Figure 3, north of the island is more suitable for industrial development. The proximity to urban infrastructure, the shape and soil have been very effective in suitability of this area.

\subsection{Ecological Suitability for the Environmental Protection}

Hormuz Island, geologically and as it emerges, is a salt dome that gradually rises from the depths of the earth, and a set of different layers such as marl, salt, anhydride, gypsum, clay and various minerals are created. From the profile of this unit are the salt domes consist of Hormuz's organization with large cuts and droplets, often without soil or with shallow soil with high salinity. The vegetation is low. Therefore, the erosion unit is very high. Coral reefs are considered as a sensitive and rare marine collection, and due to the large population of their dependent aquatic animals, they are among the living resources of the marine

Table 2. Environmental criteria for the industrial development of the island of Hormuz.

\begin{tabular}{|c|c|c|}
\hline Suggested criteria & Description & $\begin{array}{l}\text { Final } \\
\text { rating }\end{array}$ \\
\hline \multicolumn{3}{|l|}{ Climate } \\
\hline Climate & $\begin{array}{l}\text { Due to the very warm and humid climate on the island, and considering that } 100 \% \text { of the area is } \\
\text { covered by areas with low rainfall, a specific classification cannot be proposed. }\end{array}$ & \\
\hline \multicolumn{3}{|l|}{ Land form } \\
\hline Roughness & Smooth lands & 0.080 \\
\hline Slope & Up to $8 \%$ & 0.175 \\
\hline Geographical direction & North and west & 0.175 \\
\hline \multicolumn{3}{|l|}{ Soil } \\
\hline Soil type & Looney - clay loam & 0.028 \\
\hline \multicolumn{3}{|l|}{ Wind } \\
\hline Wind direction & Southwest & 0.197 \\
\hline \multicolumn{3}{|l|}{ Water resources } \\
\hline Access to water resources & 250 liters per day per person & 0.90 \\
\hline \multicolumn{3}{|l|}{ Other } \\
\hline Plant cover density & $\begin{array}{l}\text { The location of the city be not located in the forest, and at least a distance of } 5 \mathrm{~km} \text { is recommended } \\
\text { (urban development is far from the Mangrove forests) }\end{array}$ & 0.037 \\
\hline Protected areas & $\begin{array}{l}\text { Be not in areas under the management of the Environmental Protection Agency and forests and } \\
\text { pastures. Minimum distance of } 30 \mathrm{~km} \text { is recommended }\end{array}$ & 0.250 \\
\hline Access to infrastructure & $\begin{array}{l}\text { Access to gas transmission lines for various uses, highways for access to population centers and } \\
\text { transmission lines and water resources for various uses (the proposed urban expansion plan is part of } \\
\text { the current residential area and with the attention of the D \& E group's) }\end{array}$ & 0.143 \\
\hline
\end{tabular}

Source: authers. 


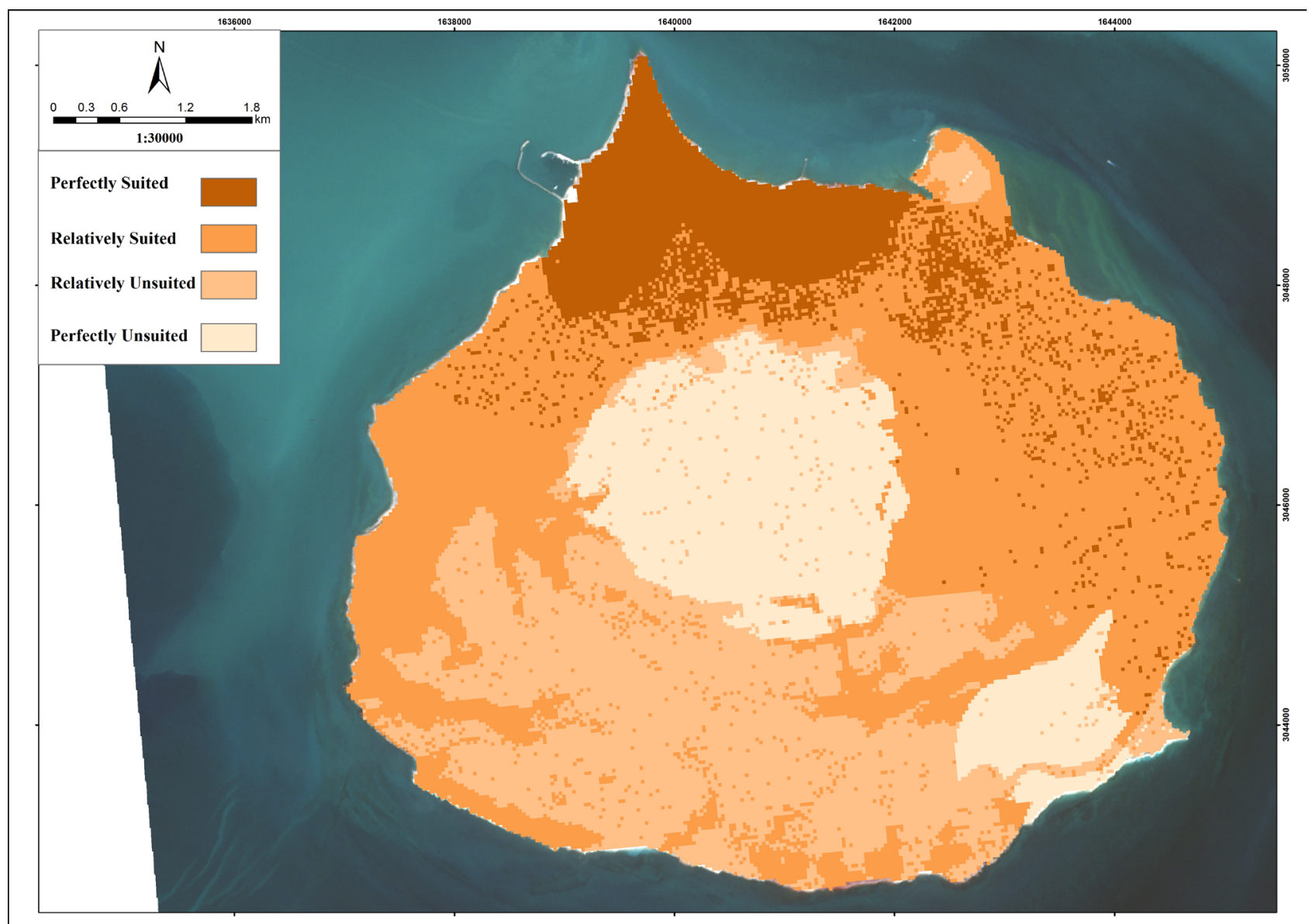

Figure 3. Hormuz Island's land suitability for industry.

ecosystem located in the eastern part of the island of Hormuz. The Mangrove forests are among the other protected habitats that are found in muddy lands, lagoons and sedimentary waters on the northeastern shores of the island. Due to their rare nature, these forests are of particular natural value in Iran's herbal collection and make a significant change in the wildlife and sea food chain. The coastal areas of Hormuzgan province are an important habitat for many species of birds and are regarded as a crossroads for migrating birds which intend to cross the Oman waters and the Persian Gulf, therefore the fauna of the birds of the Hormuzgan province is rich and about half of the birds in Iran are in the province. The island of Hormuz is no different from this rule, and the coastal Eggert and Eagle fisherman of various species of birds near the waterfront, Jiroft, lunar, and various species of tortoiseshells from the dry land, the island of Hormuz is their habitat. Also, according to field observations of the island, in the southeastern part of the island are the scattering of Chinkara (Gazella bennettii). On the south-east side of the island, on the shores of the sand, is the habitat of the sea turtle (Eretmochelys imbricate), which is endangered species. Due to the valuable habitat of the species exposed to the endangered and erosion-sensitive soils and Mangrove forests, the protection zones are classified into two categories: 1) "a safe zone" that means the tourist does not enter and 2) "a protective 
zone" which means radial determination for a safe area and the arrival of tourists and people with limitations appropriate to the capacity of the region is possible. This model shows the special landscapes for conservation. Mapping patterns are based on the habitat's vulnerability, habitat diversity, species diversity, and the degree of the natural effects. Figure 4 shows Hormuz Island's land suitability for conservation. Table 3 indicates the environmental measures and their descriptions and rates that we employed for conservation land suitability.

As you can see in the Figure 4, Salt dome lands in the center of the island, salt pond (gathering holes) in the north of the salt dome, Mangrove forests in the northeast, the eastern fluvial and the habitat of the tortoises at the southeast of the island are the lands that are perfectly suitable for conservation.

\subsection{Land Suitability for Agriculture}

The salinity of the formations on Hormuz Island has caused the vegetation to be poorer than the islands and peripheral areas such as Qeshm, Lark and coastal strip of Bandar Abbas, so that plant species are relatively limited and specific to certain species such as Acacia Nilotic, Psidium guajava, Caesalpinia, Parkinsonia, Ziziphus, (in this case, the dominant species of Plants is Acacia Nilotic, which, in terms of compatibility with the environment, more capable of growth and development, and as a shady plant it can be found in workshops, in the margin and the road outside the city and around the highways). Due to soil salinity, the composition and density of vegetation and low fertility, Hormuz Island has a lot of restrictions for agriculture, but in this situation, we can offer zones in this category, in line with the six categories of agricultural and rangel-

Table 3. Environmental criteria for the conservation development of the island of Hormuz.

\begin{tabular}{|c|c|c|}
\hline Suggested criteria & Description & $\begin{array}{l}\text { Final } \\
\text { rating }\end{array}$ \\
\hline \multicolumn{3}{|l|}{ Climate } \\
\hline Climate & $\begin{array}{l}\text { Due to the very warm and humid climate on the island, and considering that } 100 \% \text { of the area is } \\
\text { covered by areas with low rainfall, a specific classification cannot be proposed. }\end{array}$ & 0.082 \\
\hline \multicolumn{3}{|l|}{ Land form } \\
\hline Roughness & Rugged grounds & 0.82 \\
\hline Slope & More than $8 \%$ & 0.056 \\
\hline Geographical direction & South and east & 0.049 \\
\hline \multicolumn{3}{|l|}{ Erosion } \\
\hline Erosion rate & Salt dome and areas with dandruff, holes and flood plain & 0.235 \\
\hline \multicolumn{3}{|l|}{ Soil } \\
\hline Soil & Salt and calcareous & 0.105 \\
\hline \multicolumn{3}{|l|}{ Other } \\
\hline Plant cover density & Has poor vegetation & 0.145 \\
\hline Protected areas & Protected Areas of the Environment Organization- valuable species of Jabir and Turtle & 0.245 \\
\hline
\end{tabular}

Source: authers. 


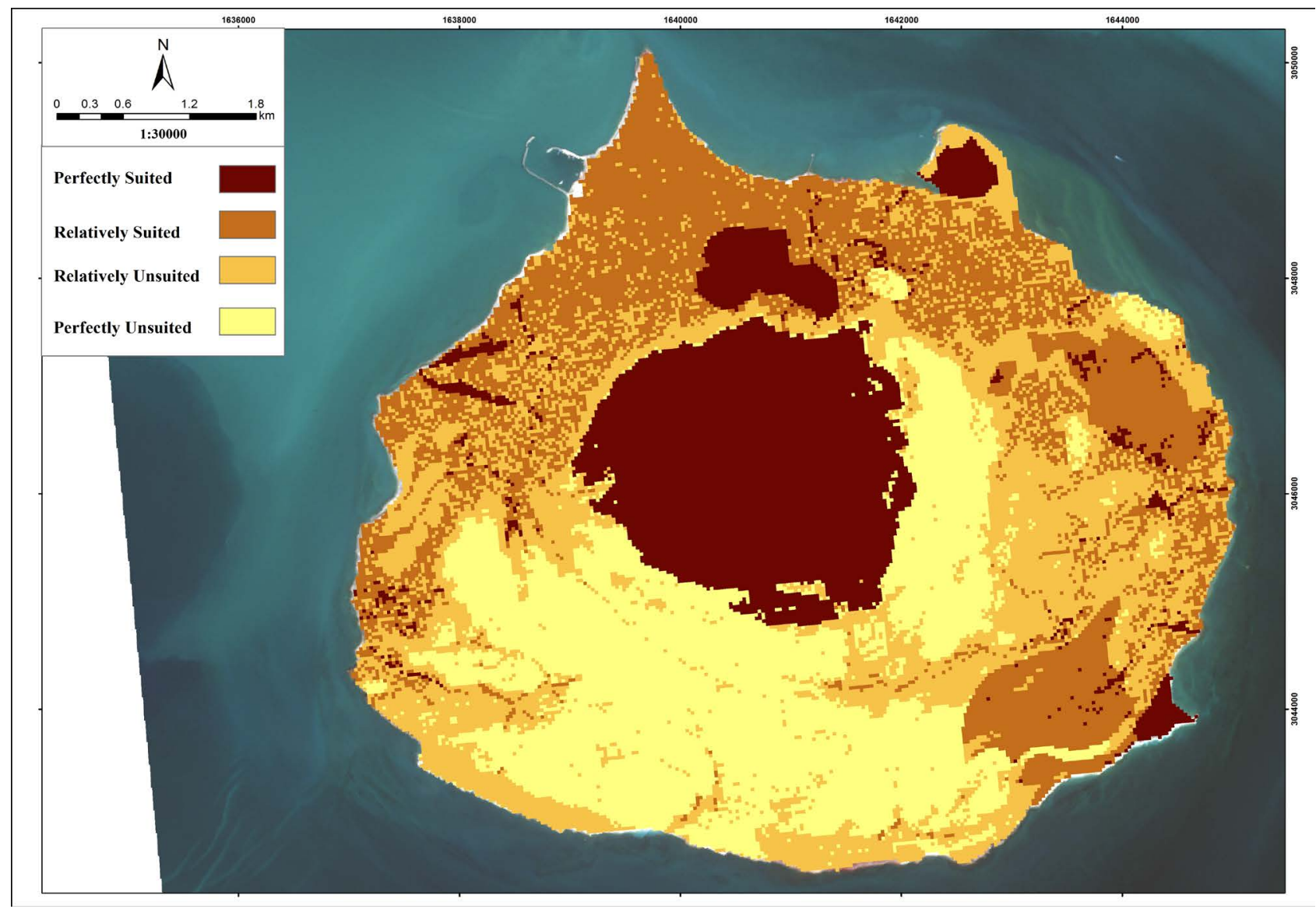

Figure 4. Hormuz Island's land suitability for conservation.

and models of Makhdoum, and the realities of the place, and in terms of the warm and humid climate of the island. Among the factors affecting agriculture, climate is all the more important. The high temperature in all seasons allows for the cultivation of tropical plants (providing water), and the concentration of precipitation in the winter $(60 \%)$, with high temperatures, allows for the possibility of farming in this season, too. Due to the fact that in this season most of the country's regions are in cold weather, Hormuzgan province can play an important role in the production of Cucurbits for the country. But the agricultural purpose of the island of Hormuz, due to the limitation of favorable land, is self-tailing and the use of special agriculture (high-yielding products such as ornamental plants) for economic development. It should be noted that other agricultural funds such as horticulture, animal husbandry cannot be planted on the island of Hormuz. Figure 5 shows Hormuz Island's land suitability for agriculture. Table 4 indicates the environmental measures and their descriptions and rates that we employed for agricultural land suitability.

As you can see in the Figure 5, Suitable lands for agricultural are concentrated mainly in the north and west of the island because of the quality and type of soil. In the northern part, the urban texture allows the development of green space and domestic agriculture, and the western lands of vegetation require mainten- 
Table 4. Environmental criteria for agricultural use of Hormuz Island.

\begin{tabular}{lll}
\hline \multicolumn{1}{c}{ Suggested criteria } & \multicolumn{1}{c}{ Description } & Final rating \\
\hline Climate & $\begin{array}{l}\text { The proposed species for agriculture should be commensurate with the climate and compatible with it. } \\
\text { Annual precipitation is less than } 400 \text { millimeters a year. }\end{array}$ \\
Land form & $15-30 \%$ & 0.065 \\
Slope & South and southeast \\
Slope direction & Fairly smooth grounds \\
Roughness & Clay sand, clay loamy sandstone, clay loam medium to large gravel \\
Soil & \\
Soil type & Medium and semi-deep soil texture \\
Other & Vegetation from 25 to 50 percent \\
Erosion & Proximity to surface water sources. In the whole island, water is needed in this area. \\
Plant cover density & Out of range of protected areas with sensitive and vulnerable characteristics \\
Access to water resources & 0.145 \\
Protected areas &
\end{tabular}

Source: authers.

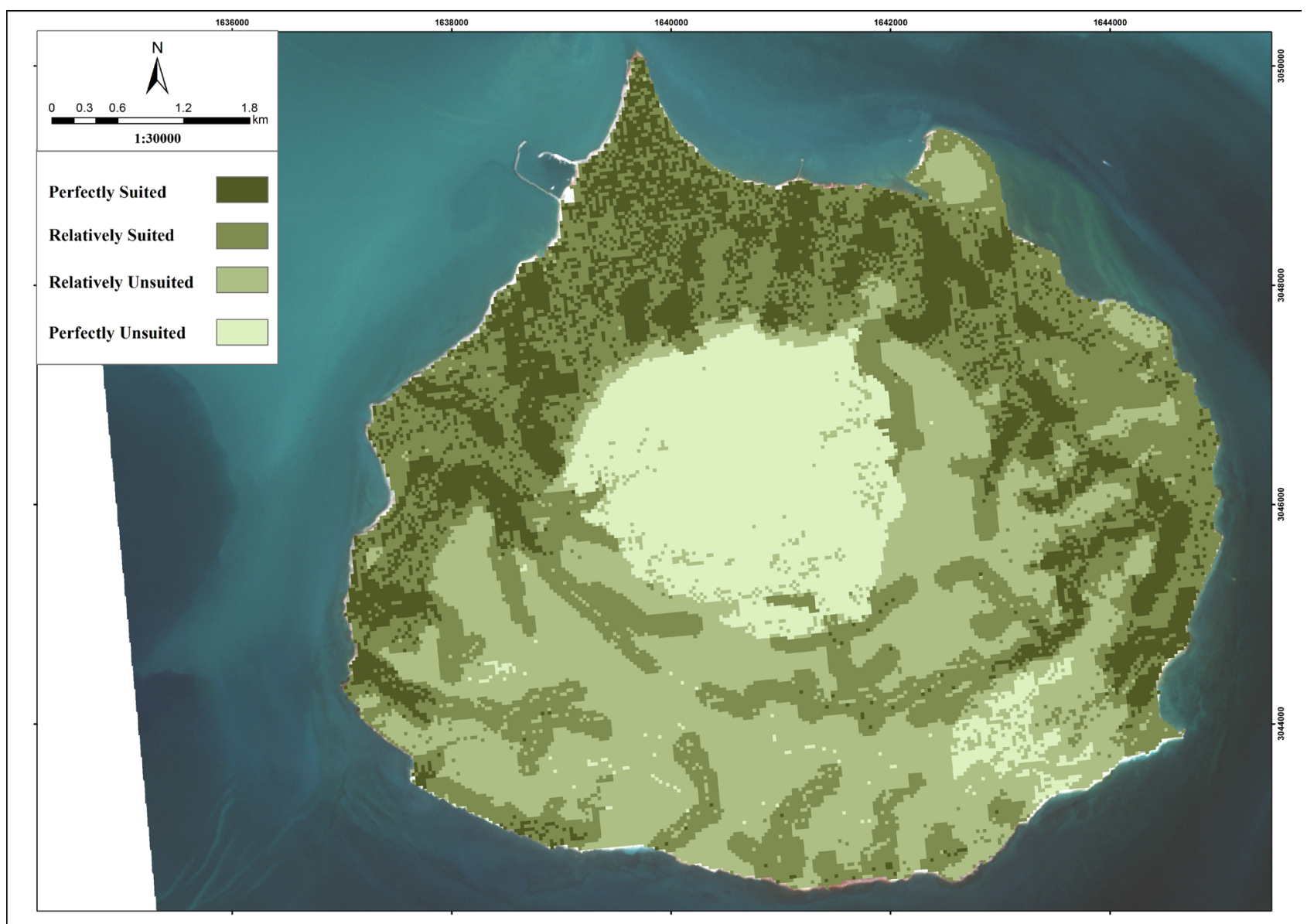

Figure 5. Land suitability of Hormuz Island for agriculture. 
ance and conservation that is appropriate for the tourism approach, and agriculture with economic objectives in this area is not feasible. Therefore, in the eastern lands, which are more limited, the agricultural area should be considered as an agricultural area. Styles named "Heading 1", "Heading 2", "Heading 3", and "Heading 4" are prescribed.

\section{Conclusions}

Hormuz Island not only has a strategic situation but also has many human and natural attractions. However, this Island is less developed area and faced with many socio-economic and environmental challenges and problems and its environment is very sensitive to developmental plans and projects. Therefore, the sustainable development plan on the island should be formulated and implemented with the first priority of environmental sustainability. In this regard, one of the most important factors influencing sustainable development is the proper establishment of the activities in proportion to environmental indicators. Therefore, the evaluation of land suitability is the first step in the development of the Island.

In this paper, we identified the appropriate environmental indicators for tourism, industrial, conservation and agriculture activities. The results show that the northern lands of the island (the city of Hormuz and its coastal strip), and the tourist attractions of the south, east and west of the island (mainly around the coastal strip) are appropriate for tourism activities, the lands of the East and West of Hormuz (close to the infrastructure) for industrial development, central lands (salt domes) and southeast (habitat of Turtle and Gazella) and northeastern (Mangrove forests) are suitable for conservation and the eastern and western lands are sporadic and limited for agricultural development. Agricultural development should be planned to take into account water supply resources, and it is better to concentrate on high-quality agriculture such as ornamental plants and self-tailing of the island residents in providing Cucurbits supplies.

\section{References}

[1] Atalay, I. (2016) A New Approach to the Land Capability Classification: Case Study of Turkey. Procedia Environmental Sciences, 32, 264-274. https://doi.org/10.1016/j.proenv.2016.03.031

[2] Naghsh Click International Information Processing Company (2017) The Sustainable Development Plan of the Island of Hormuz. Naghsh Click International Information Processing Company, Isfahan.

[3] Hopkins, L.D. (1977) Methods for Generating Land Suitability Maps: A Comparative Evaluation. Journal of the American Planning Association, 43, 386-400.

[4] Basinski, J.J. (1985) Land Elevation Some General Consideration. In: Basinski, J.J. and Cocks, K.D., Eds., Environmental Planning and Management, CSIRO, Canberra, 59-65.

[5] AbdelRahman, M.A.E., Natarajan, A. and Hegde, R. (2016) Assessment of Land Suitability and Capability by Integrating Remote Sensing and GIS for Agriculture in 
Chamarajanagar District, Karnataka, India, The Egyptian Journal of Remote Sensing and Space Sciences, 19, 125-141. https://doi.org/10.1016/j.ejrs.2016.02.001

[6] Gad, A. (2015) Land Capability Classification of Some Western Desert Oases, Egypt, Using Remote Sensing and GIS. The Egyptian Journal of Remote Sensing and Space Sciences, 18, 9-18. https://doi.org/10.1016/j.ejrs.2015.06.002

[7] Jozi, S.A., Zaredar, N. and Rezaeian, S. (2010) Evaluation of Ecological Capability using Spatial Multi Criteria Evaluation Method (SMCE) Case study: Implementation of Indoor Recreation in Varjin Protected Area-Iran. International Journal of Environmental Science and Development, 1, No. 3. https://doi.org/10.7763/IJESD.2010.V1.53

[8] Pamungkas, A., Sulistyono, A. and Siswanto, V.K. (2016) Poteran Carrying Capacity for Small Island Development. Procedia-Social and Behavioral Sciences, 227, 761769. https://doi.org/10.1016/j.sbspro.2016.06.143

[9] Silpa, T., Ja, M. and Nowshaja, P.T. (2016) Land Capability Classification of Ollukara Block Panchayat Using GIS. Procedia Technology, 24, 303-308. https://doi.org/10.1016/j.protcy.2016.05.040

[10] Noraei, I., Balist, J. and Karimi, S. (2015) Ecological Capability Evaluation to Determine Suitable Areas for Agriculture Using Fuzzy Logic and AHP Technique. American-Eurasian Journal of Sustainable Agriculture, 9, 35-43.

[11] Ritung, S., Wahyunto, A.F. and Hidayat, H. (2007) Land Suitability Evaluation with a Case Map of Aceh Barat District. Indonesian Soil Research Institute and World Agroforestry Centre, Bogor and Nairobi.

[12] Pirmohammadi, Z., Feghhi, J., Amiri, G.Z. and Sharifi, M. (2010) Environmental Capability Evaluation Appropriate to Ecotourism in Zagros Forests, Case Study: Saman-E-Orfie Cham-Haji of Kakareza Forest in Lorestan Province. Iranian Journal of Forest and Poplar Research, 18, 230-241.

[13] Makhdoom, M. (2005) The Basics of the Land. 4th Edition, Tehran University Press, Tehran, 244.

[14] Zeinivand, H., Borzoei, N. and Maleknia, R. (2014) Ecological Capability Evaluation of Taf Traditional-Property for Intensive Recreation Based on MCDM. Agriculture Science Developments, 3, 175-182.

[15] Mohammady, P. and Amid, A. (2010) Integrated Fuzzy VIKOR and Fuzzy Model for Supplier Selection in an Agile and Modular Virtual Enterprise; Application of FMCDM on Service Companies. Journal of Mathematics and Computer Science, 1 , 413-434.

[16] Mansir, A. (2007) A Geographic Information System and Multi-Criteria Analysis for Sust Malczewski Enable Tourism Planning. Master's Thesis, Universiti Teknologi Malaysia, Johor Bahru.

[17] Qiao, L. (2008) A Model for Suitability Evaluation of Tourism Development for the Suburban Mining Wasteland and Its Empirical Research. Ecological Economy, 4, 338-345.

[18] Reshmidevi, T.V., Eldho, T.L. and Jana, R. (2009) A GIS-Integrated Fuzzy RuleBased Inference System for Land Suitability Evaluation in Agricultural Watersheds. Agricultural Systems, 101, 101-109. https://doi.org/10.1016/j.agsy.2009.04.001

[19] Miardavidi, H., et al. (2007) Investigation and Determination of Ecological Capability of Markazi Province in Terms of Agriculture and Range Management Using Geographic Information System (GIS). Journal of Rangeland and Desert Research, 15, 242-255. 
[20] Mahmoudi, B. (2007) Evaluation of Salmon Capacity in the Ordinary Manjan Forest in the County of Lordegan in Chaharmahal and Bakhtiari Province. Master's Thesis, Natural Resources Faculty of Sari, Mazandaran University, Babolsar, 112.

[21] Minaai, M. (2009) Implementation of Agricultural Research Model Using Fuzzy Area and Geographic Information System (Geographical Information System): (Case Study of Fereidoun City). Master's Thesis, Faculty of Geography, Tehran University, Tehran, 146.

[22] Faraji Sabokbar, H. (2005) Site Selection for Business Services Using Analytic Hierarchy Process. Geographical Research, 37, 125-138.

[23] Gholi, Y., Vahid, A.Z.K. and Soltani, A. (2016) Determination of Suitable Land for Urban Development Using Hierarchical Process Analysis (Analytical Hierarchy Process), Case Study: Zanjan City. 8, 190-173.

Submit or recommend next manuscript to SCIRP and we will provide best service for you:

Accepting pre-submission inquiries through Email, Facebook, LinkedIn, Twitter, etc. A wide selection of journals (inclusive of 9 subjects, more than 200 journals) Providing 24-hour high-quality service User-friendly online submission system Fair and swift peer-review system Efficient typesetting and proofreading procedure Display of the result of downloads and visits, as well as the number of cited articles Maximum dissemination of your research work

Submit your manuscript at: http://papersubmission.scirp.org/ Or contact oje@scirp.org 